\title{
Linking fluctuations in rainfall to nonbreeding season performance in a long-distance migratory bird, Setophaga ruticilla
}

\author{
Colin E. Studds ${ }^{1,2, *}$, Peter P. Marra ${ }^{2}$ \\ ${ }^{1}$ Program in Behavior, Ecology, Evolution, and Systematics, University of Maryland, College Park, Maryland 20742, USA \\ ${ }^{2}$ Smithsonian Migratory Bird Center, National Zoological Park, Washington, DC 20008, USA
}

\begin{abstract}
Research on long-distance migratory birds has yielded some of the strongest evidence that shifts in climate are changing ecosystem processes. Much of this work has focused on understanding whether rising temperatures on temperate breeding grounds are advancing migration phenology and limiting reproductive success. However, conditions on tropical nonbreeding quarters can also shape these processes, yet few studies have directly measured bird responses to climate during this part of the annual cycle. We tested the hypothesis that variation in winter rainfall can influence food availability and the nonbreeding season performance of American redstarts Setophaga ruticilla occupying 2 contrasting habitats: wet, mangrove forest and dry, second-growth scrub. From 2002 to 2005, food availability, body mass, and spring departure schedules of birds in both habitats were highly dependent on rainfall. Food availability in mangrove forest was higher than in second-growth scrub in 3 out of $4 \mathrm{yr}$, allowing birds in this habitat to maintain better physical condition through the winter and depart earlier on spring migration. However, abundant rainfall in the spring of 2004 led to abnormally high food availability in scrub and early departure of birds in both habitats. These results suggest that rainfall on tropical wintering areas can have major effects on the nonbreeding season performance of migratory birds, and that the timing of rainfall within the dry season, not just the absolute amount, may be critical for orchestrating migratory departure schedules. Because rainfall in tropical regions is projected to decline drastically over the next $50 \mathrm{yr}$, migratory birds could face increasingly severe food shortages prior to spring migration. Such conditions could force departure schedules to become delayed and constrain adaptation to selection for earlier breeding in response to rising temperatures at breeding areas.
\end{abstract}

KEY WORDS: American redstart - Climate change - Migratory birds - Seasonal interactions · Setophaga ruticilla $\cdot$ Spring migration

\section{INTRODUCTION}

It is now clear that persistent shifts in climate are altering the structure and function of ecosystems worldwide (Walther et al. 2002, Parmesan \& Yohe 2003, Root et al. 2003). Despite their astounding taxonomic diversity, many birds share several life-history traits that have made them instrumental for evaluating the consequences of changing climate: they are widely distributed, highly mobile, their annual cycles hinge on seasonal phenological cues, and they have rela- tively short generation times. Among the most prominent examples of such research are studies measuring bird responses to rising temperatures along migratory routes or on temperate breeding areas. Coincident with warming temperatures, many species in both Europe and North America have advanced their breeding ground arrival dates (Cotton 2003, MurphyKlassen et al. 2005), begun breeding earlier (Crick et al. 1997, Dunn \& Winkler 1999), and extended their ranges poleward (Thomas \& Lennon 1999, Hitch \& Leberg 2007). In other species, arrival times at breed- 
ing areas have remained unchanged as temperatures have increased (Mills 2005), or have not advanced enough to remain in synchrony with changes in resource phenology at lower trophic levels (Both \& Visser 2001). The direction and magnitude of phenological shifts have also been shown to vary across the breeding range for the same species (Both et al. 2004, Both \& te Marvelde 2007, this issue). This heterogeneity in response among species and regions suggests that temperature on breeding areas is not the only factor altering annual life cycle events of migratory birds. Trends toward earlier arrival and breeding time also could be caused by changes in departure schedules from the wintering grounds, or by changes in the pace of migration. For the latter there is considerable correlative data (Forchhammer et al. 2002, Marra et al. 2005, Hüppop \& Winkel 2006), but whether departure dates from winter quarters are affected by climatic variables is largely unknown.

Substantial evidence suggests that rainfall during the nonbreeding season can have important consequences for migratory birds. Rainfall and temperature on the nonbreeding quarters in Africa have been shown to influence abundance, first arrival dates, and annual survival at breeding areas in Europe (Møller 1989, Kanyamibwa et al. 1990, Peach et al. 1991, Szép 1995, Barbraud et al. 1999, Gordo et al. 2005). Indices of global climate cycles (e.g. El Niño Southern Oscillation, ENSO), which correlate well with temporal rainfall dynamics, have also been linked to the annual survival of migratory birds wintering in the Caribbean (Sillett et al. 2000) and the breeding ground arrival schedules of birds spending the nonbreeding period in Africa (Cotton 2003). Recent advances in the application of remote sensing using the normalized difference vegetation index (NDVI) have broadened the scale and level of resolution with which ecological responses to precipitation can be examined (Pettorelli et al. 2005). Consistent with previous research, these studies find tight associations between NDVI data and breeding ground arrival time (Saino et al. 2004), annual survival (Szép \& Møller 2005), and the onset of breeding (Both et al. 2006).

Rainfall patterns stemming from broad-scale climate cycles can have direct and indirect effects on plant productivity (Oba et al. 2001, Nemani et al. 2003), insect abundance (Polis et al. 1997), and food plant quality for phytophagous insects (Huberty \& Denno 2004), all of which may determine food availability for migratory birds. Multiple lines of evidence suggest that food is a key limiting factor for migratory birds during the nonbreeding period, particularly during the late-winter dry season (Sherry et al. 2005, Brown \& Sherry 2006, Johnson et al. 2006). Late-winter dry seasons are commonplace in sub-equatorial regions and have been linked to seasonal declines in arthropod populations in tropical deciduous forests through both observations and experiments (Janzen 1973, Wolda \& Wright 1992, Lefebvre et al. 1994, Parrish \& Sherry 1994). The late-winter dry season in many tropical locations is a critical time for migrants because of premigratory fattening (Brown \& Sherry 2006), molt in some species (van den Brink et al. 2000), and the need to arrive at breeding areas in optimal condition and as early as possible (Marra et al. 1998, Norris et al. 2004). To date, few studies have examined how rain and food on nonbreeding quarters interact to affect the physical condition and performance of migratory birds (Brown \& Sherry 2006). Consequently, it is unclear how annual variation in nonbreeding season rainfall is likely to influence the timing of departure on spring migration.

Research on wintering populations of American redstarts Setophaga ruticilla in wet, mangrove forest and dry, second-growth scrub illustrates a tight linkage between moisture and bird performance. By the end of the winter dry season in Jamaica, the availability of arthropods consumed as prey is lower in secondgrowth scrub than in mangrove forest (Studds \& Marra 2005). This difference in food availability appears to affect multiple measures of redstart performance. Relative to redstarts occupying mangrove forest, birds in dry scrub have elevated corticosterone levels (Marra \& Holberton 1998), lose mass over winter (Marra \& Holmes 2001), depart later on spring migration (Marra et al. 1998, Studds \& Marra 2005), and have lower annual survival (Johnson et al. 2006). Redstarts occupying dry winter habitats also arrive later at breeding areas, may be in poor physical condition upon arrival, and fledge fewer young compared to birds originating from wet locales (Marra et al. 1998, Norris et al. 2004). Moisture gradients across these habitats, therefore, appear to drive food availability and, ultimately, the performance of American redstarts throughout their annual cycle. However, we have not, until now, examined how the habitat-specific performance of redstarts changes in response to annual variation in rainfall.

We tested the hypothesis that changes in rainfall across years can drive spatio-temporal variation in the nonbreeding season performance of American redstarts (Fig. 1). We predicted that differences in rainfall among years would lead to parallel variation in the abundance of arthropods available as prey, redstart physical condition, and the timing of departure on spring migration. Because mangrove forest retains standing water, we also predicted that birds in this habitat would be buffered from annual fluctuations in rainfall and food availability, allowing them to maintain superior physical condition and to depart earlier on spring migration relative to redstarts in second-growth scrub. 


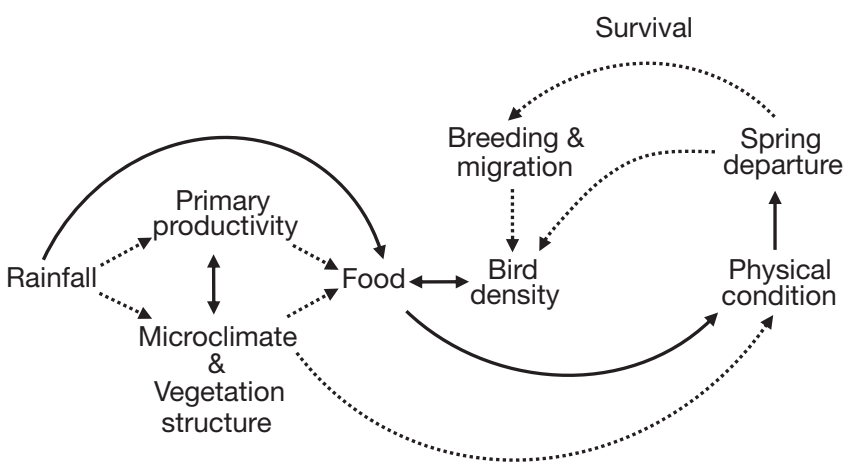

Fig. 1. Setophaga ruticilla. Hypothesized influence of nonbreeding season rainfall on the performance of American redstarts throughout their annual cycle. Solid arrows: pathways examined in the present study; dashed arrows: other potential effects

\section{MATERIALS AND METHODS}

We conducted this research at the Font Hill Nature Preserve $\left(18^{\circ} 02^{\prime} \mathrm{N}, 77^{\circ} 57^{\prime} \mathrm{W},<5 \mathrm{~m}\right.$ above sea level), about $13 \mathrm{~km}$ west of Black River, St. Elizabeth Parish, Jamaica. This area is one of the driest in Jamaica ( $<1000 \mathrm{~mm}$ of rain per year), and, as is typical of many tropical regions, experiences strong seasonality in precipitation. Rainfall is high from August through November, when average monthly rainfall typically exceeds $100 \mathrm{~mm}$, and then usually declines to $<25 \mathrm{~mm}$ $\mathrm{mo}^{-1}$ during the dry season from January through March (Jamaica Meteorological Service unpubl. data).

American redstarts were studied in 2 habitat types: wet, mangrove forest and dry, second-growth scrub. Mangrove forest was dominated by black mangrove Avicennia germinans, but also had some white Languncularia recemosa and red mangrove Rhizophora mangle. Trees in this habitat ranged from 8 to $>75 \mathrm{~cm}$ diameter at breast height ( $\mathrm{dbh})$, were regularly distributed at intervals of 10 to $15 \mathrm{~m}$, and had dense canopies averaging about $12 \mathrm{~m}$ in height. Mangrove stands were usually inundated with 0.5 to $1.0 \mathrm{~m}$ of standing water through January, but became progressively drier in February and March, drying out entirely in some years. Despite annual variation in surface water, mangrove trees retained the majority of their leaves during the dry season, keeping this habitat relatively cool and shady throughout the time when redstarts were present. Vegetation in second-growth scrub was dominated by logwood trees Haematoxylon campechianum, a thorny species with a fluted trunk, but also contained several less common species, including Bursera simarubra, Terminalia latifolia, and Crescentia alata. Trees in this habitat were generally 2 to $8 \mathrm{~cm}$ dbh, grew from 3 to $10 \mathrm{~m}$ in height, and were interspersed with small, grassy fields and dense tangles of vines and shrubs. Unlike mangrove habitat, secondgrowth scrub never had standing water, and trees and other vegetation dropped most of their leaves during the dry season. Further description of the study area can be found in Marra \& Holmes (2001).

In spring (15 March to 15 April) of 2002 to 2005, redstarts were captured in mist nets, aged and sexed using criteria from Pyle (1997) and Marra et al. (1993), fitted with a unique color scheme of plastic leg bands and USFWS aluminum bands, measured for body size, weighed to the nearest $0.1 \mathrm{~g}$, and released. Redstart mass during this period reflects physical condition at the end of the late-winter dry season, when birds typically carry little or no visible subcutaneous fat. To delineate territory boundaries, we followed and mapped color-banded birds for a minimum of $3 \mathrm{~h}$ spread across at least 1 mo. From 1 April to 15 May of each year, we resighted color-banded birds at $3 \mathrm{~d}$ intervals to determine their timing of departure on spring migration. When observers failed to resight a bird, its territory was visited twice more during that $3 \mathrm{~d}$ period, and then once again in the next $3 \mathrm{~d}$ period using a song-chip playback to confirm departure. To minimize the effect of time dependency of bird sampling, we captured redstarts in mangrove and scrub habitats on alternating days and monitored a roughly equal number of territories in each habitat during each $3 \mathrm{~d}$ interval of the spring departure period.

Arthropods available as redstart prey were measured in both habitats within 2 wk of bird capture on a subset of territories. One observer made 20 passes of a sweep net over green vegetation while walking a circular route through the territory. The sweep net was fastened to a $5 \mathrm{~m}$ extension pole, allowing arthropods to be sampled from within the foraging height range of redstarts. The contents of the sweep net were overturned into a plastic bag and placed overnight in a freezer $\left(-10^{\circ} \mathrm{C}\right)$, preserved in $70 \%$ ethanol, and later dried at $50^{\circ} \mathrm{C}$ for $24 \mathrm{~h}$. All arthropods $>2 \mathrm{~mm}$ in length that are typically found in regurgitation and fecal samples (Sherry \& Holmes 1997) were then weighed $( \pm 0.1 \mathrm{mg})$ to yield a single measure of food availability at each territory.

Trends in January through March rainfall from 1995 to 2005 were analyzed with Pearson's correlation. We developed an estimate of redstart body mass corrected for the body size of each bird by first reducing data on unflattened wing chord, tarsus size, and tail length onto a single axis using principal components analysis (PCA). We then regressed body mass on the standardized factor scores from the PCA and used the residual values as an estimate of corrected body mass. Data on corrected body mass and arthropod biomass were examined using a general linear model (GLM) that included age, sex, and habitat occupancy as fixed 
effects, total rainfall from January through March of each year as a linear covariate, and all 2-way interactions between demographic groups and environmental variables. We also included the day of the year of capture as a covariate in the analysis of corrected body mass to adjust for potential variation in redstart mass across the 1 mo capture period. The relationship between corrected body mass and spring departure dates was evaluated with ordinary least-squares regression. We did not analyze spring departure schedules from 2002 because birds were not monitored for the entire departure period in this year. All data met the assumptions of parametric tests, so no transformations were necessary. Analyses were done with SAS 8.2 (SAS Institute 1999).

\section{RESULTS}

From 1995 to 2005, dry-season rainfall (January through March) decreased by approximately $17 \%$ $(r=0.64, n=11, p=0.03$; Fig. 2). The timing of precipitation also became more variable through time, as indicated by the increasing coefficient of variation for rainfall within the dry season of each year $(\mathrm{r}=0.65, \mathrm{n}=$ $11, p=0.03$ ). The increasing unpredictability of dry season precipitation is particularly evident in recent years. For example, in 2004, $185 \mathrm{~mm}$ of rain fell across the entire dry season, of which $108 \mathrm{~mm}$ came in March (Fig. 2), making this the second wettest spring since 1995. In contrast, 2005 was one of the driest years on record in Jamaica, with only $3 \mathrm{~mm}$ of rain in March.

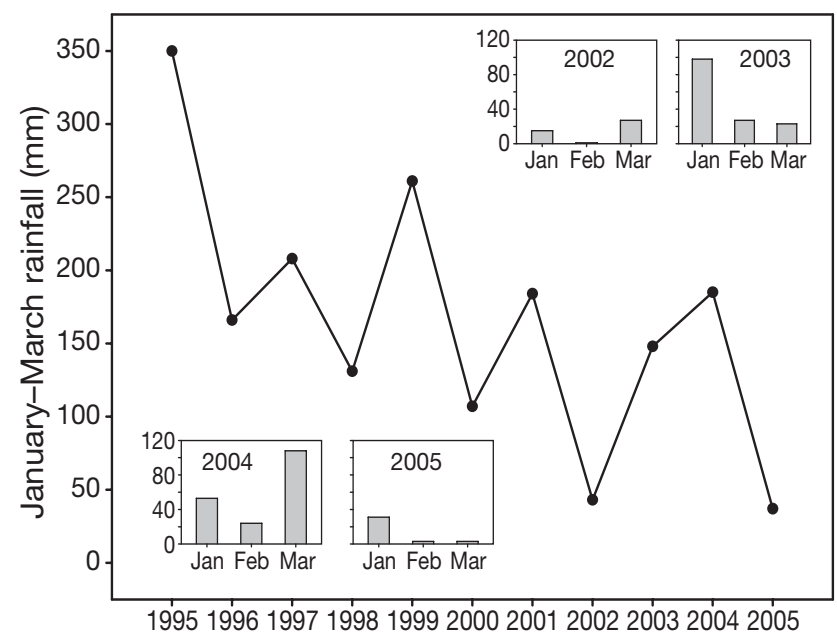

Fig. 2. Trends in dry-season rainfall (January through March) from 1995 to 2005 at the Burnt Savannah climate monitoring station in Jamaica, West Indies, approximately $10 \mathrm{~km}$ northwest of the nonbreeding site where American redstarts in this study were monitored. Insets show the monthly distributions of dry-season rainfall during this study from 2002 to 2005. Data were provided by the Jamaica Meteorological Service
During the dry seasons of 2002 to 2005, the biomass of arthropods available as prey to American redstarts was greater in years of high rainfall in both mangrove forest and second-growth scrub (GLM for Rainfall: $F_{1,51}=4.96, \mathrm{p}=0.03$; for Rainfall $\times$ Habitat: $F_{1,51}=2.00$, $\mathrm{p}=0.16$; Fig. 3). On average, redstarts in mangrove had higher arthropod biomass on their territories compared to those in scrub (GLM for Habitat: $F_{1,51}=15.75$, $p=0.0002$; Fig. 3). The variation in food availability between habitats was pronounced in 3 out of $4 \mathrm{yr}$ (2002: $20.9 \pm 2.8 \mathrm{mg}$ in mangrove, $2.6 \pm 3.0 \mathrm{mg}$ in scrub; means $\pm \mathrm{SE}_{;}$2003: $18.1 \pm 3.0 \mathrm{mg}$ in mangrove, $4.1 \pm$ $2.6 \mathrm{mg}$ in scrub; 2005: $12.5 \pm 1.9 \mathrm{mg}$ in mangrove, $4.4 \pm$ $2.4 \mathrm{mg}$ in scrub). However, in the extremely wet spring of 2004 (Fig. 2), arthropod biomass in scrub was roughly equal to that in mangrove $(18.2 \pm 1.9 \mathrm{mg}$ in mangrove, $18.8 \pm 3.1 \mathrm{mg}$ in scrub). These spatio-temporal differences in food availability held for all age and sex classes (GLM for Age: $F_{1,51}=1.33, \mathrm{p}=0.25$; for Age $\times$ Rainfall: $F_{1,51}=0.00, \mathrm{p}=0.96$; for Age $\times$ Habitat: $F_{1,51}=1.74, \mathrm{p}=0.19 ;$ for Sex: $F_{1,51}=0.21, \mathrm{p}=0.65 ;$ for Sex $\times$ Rainfall: $F_{1,51}=0.05, \mathrm{p}=0.82$; for Sex $\times$ Habitat: $F_{1,51}=0.08, \mathrm{p}=0.78$ ).

When corrected for their body size, the spring body mass of redstarts was higher in years of greater rainfall, an effect that was similar between habitats (GLM for Rainfall: $F_{1,214}=20.80, \mathrm{p}<0.0001$; for Rainfall $\times$ Habitat: $F_{1,214}=1.20, \mathrm{p}=0.27$; Fig. 4). Birds overwintering in mangrove forest had higher corrected mass compared to those in second-growth scrub in all $4 \mathrm{yr}$ (GLM for Habitat: $F_{1,214}=9.73, p=0.002$; Fig. 4). These patterns of corrected body mass were not dependent on the date individual birds were captured (GLM for Capture Date: $F_{1,214}=2.06, \mathrm{p}=0.15$ ) and were con-

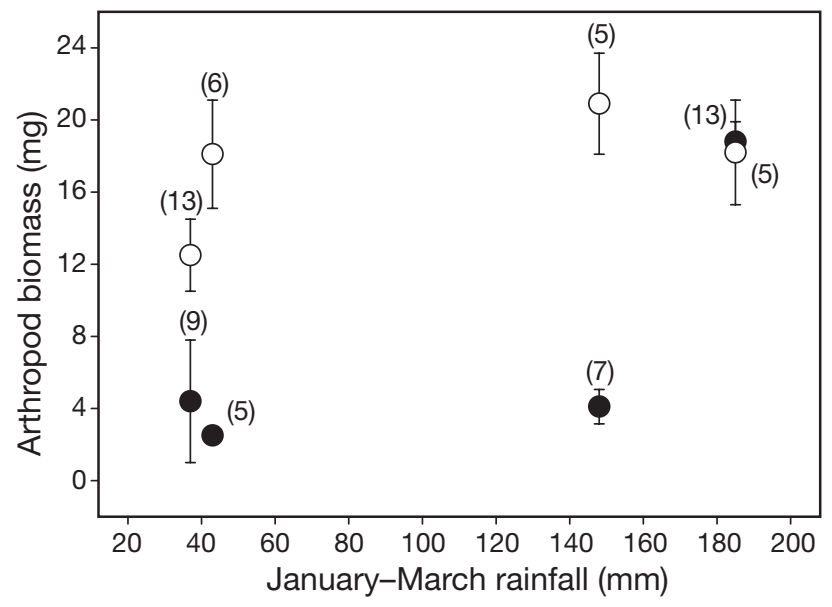

Fig. 3. Relationship between dry-season rainfall (January through March) from 2002 to 2005 and arthropod biomass (mean $\pm \mathrm{SE}$ ) in the territories of American redstarts in mangrove forest (open circles) and second-growth scrub (filled circles) at a nonbreeding site in Jamaica, West Indies. Sample sizes are shown in parentheses 


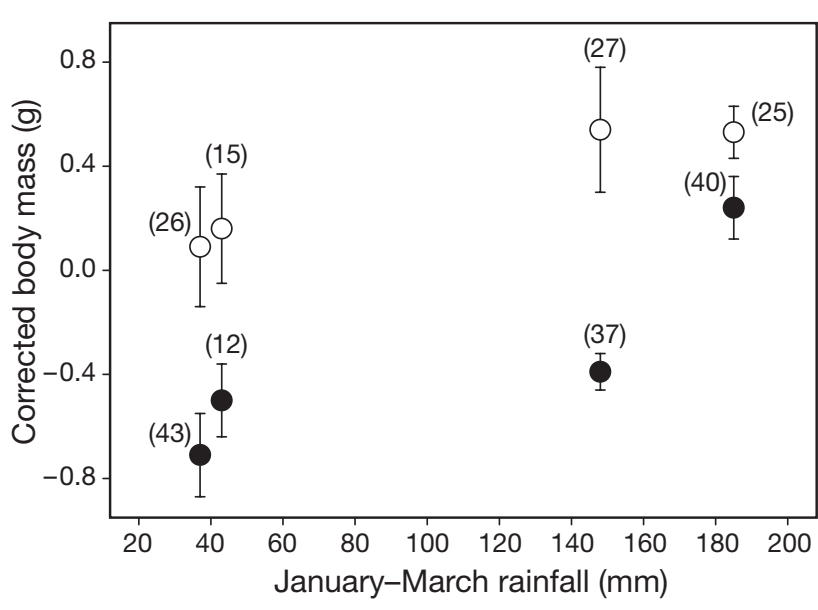

Fig. 4. Setophaga ruticilla. Relationship between dry-season rainfall (January through March) from 2002 to 2005 and the corrected body mass (mass adjusted for unflattened wing chord, tail length, and tarsus size; mean \pm SE) of American redstarts overwintering in mangrove forest (open circles) and second-growth scrub (filled circles) at a nonbreeding site in Jamaica, West Indies. Sample sizes are shown in parentheses sistent for all age and sex classes (GLM for Age: $F_{1,214}$ $=1.10, \mathrm{p}=0.30 ;$ for Age $\times$ Rainfall: $F_{1,214}=0.01, \mathrm{p}=$ 0.93 ; for Age $\times$ Habitat: $F_{1,214}=1.50, \mathrm{p}=0.22$; for Sex: $F_{1,214}=1.06, \mathrm{p}=0.31$; for Sex $\times$ Rainfall: $F_{1,214}=0.07$, $\mathrm{p}=0.79$; for Sex $\times$ Habitat: $F_{1,214}=0.19, \mathrm{p}=0.66$ ).

In 2003 and 2005, redstarts with higher corrected body mass departed earlier on spring migration compared to birds with lower mass (2003: $\mathrm{r}^{2}=0.17, \mathrm{p}=$ 0.02, $\mathrm{n}=35 ;$ 2005: $\mathrm{r}^{2}=0.15, \mathrm{p}=0.03, \mathrm{n}=30$; Fig. 5A,C). In these years, birds in mangrove forest left on migration before those in second-growth scrub (KaplanMeier $\log$ rank test for 2003: $\chi^{2}=7.55, \mathrm{p}=0.006, \mathrm{n}=35$; $29 \pm 1 \mathrm{~d}$ since 1 April for mangrove; $36 \pm 1 \mathrm{~d}$ since 1 April for scrub; mean $\pm S E$; for 2005: $\chi^{2}=3.85, \mathrm{p}=0.04$, $\mathrm{n}=30 ; 32 \pm 2 \mathrm{~d}$ since 1 April for mangrove; $38 \pm 2 \mathrm{~d}$ since 1 April for scrub). In contrast, corrected mass in 2004 was not a good predictor of spring departure schedules (2004: $\mathrm{r}^{2}=0.01, \mathrm{p}=0.43, \mathrm{n}=47$; Fig. 5B), and there was no difference in the timing of departure between habitats (Kaplan-Meier log rank test for 2004: $\chi^{2}=0.86, \mathrm{p}=0.35, \mathrm{n}=47 ; 30 \pm 1 \mathrm{~d}$ since 1 April for man-

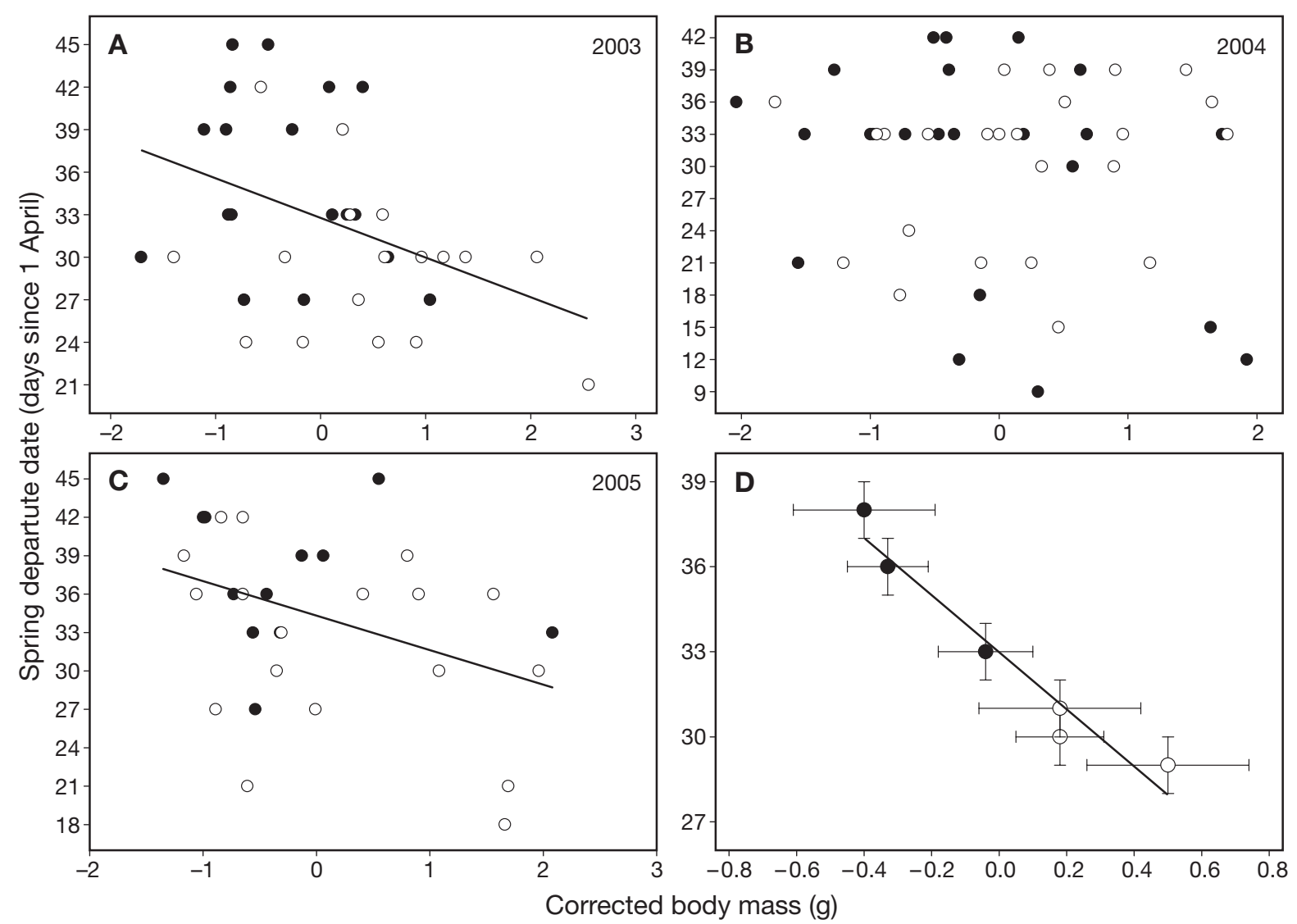

Fig. 5. Setophaga ruticilla. (A-C) Relationship between the corrected body mass (mass adjusted for unflattened wing chord, tail length, and tarsus size) of American redstarts in mangrove forest (open circles) and second-growth scrub (filled circles) and their timing of departure on spring migration (mean \pm SE) in each year from 2003 to 2005 at a nonbreeding site in Jamaica, West Indies. (D) Relationship between corrected body mass (mean \pm SE) and the timing of departure on spring migration (mean \pm SE) averaged for all birds in each habitat in each year shown in Panels A to C 
grove; $30 \pm 2 \mathrm{~d}$ since 1 April for scrub). When departure schedules from all $3 \mathrm{yr}$ were considered together, the average corrected body mass of all redstarts in each habitat was highly negatively correlated with the average date of departure on spring migration. $\left(\mathrm{r}^{2}=\right.$ 0.86, $\mathrm{p}=0.001, \mathrm{n}=6$; Fig. 5D).

\section{DISCUSSION}

Previous research has demonstrated that nonbreeding season rainfall can have important consequences for the phenology of migration and the timing of reproduction in migratory birds (Saino et al. 2004, 2007, this issue, Gordo et al. 2005, Both et al. 2006). Such findings have led to the hypothesis that rainfall mediates the timing of departure on spring migration by influencing food availability for birds during the critical period of pre-migratory fueling (Forchhammer et al. 2002, Gordo et al. 2005). This idea has remained largely untested because few studies have directly measured rain-induced shifts in food supply and their consequences for nonbreeding season performance (Brown \& Sherry 2006). Our results indicate that annual shifts in nonbreeding season rainfall influence food availability for American redstarts during the late-winter dry season, leading to marked differences in physical condition prior to migration, and, ultimately, to variation in spring departure schedules among years. Food availability for redstarts changed not only with annual variation in rainfall, but also with spatial differences in habitat moisture. In 3 out of $4 \mathrm{yr}$, food availability for birds in mangrove was higher, enabling them to maintain superior physical condition and depart earlier on migration compared to birds in scrub.

The within-year relationships between spring body mass and the timing of departure on migration illustrate how temporal trends in rainfall and spatial gradients in habitat moisture can interact to shape spring departure schedules. In both 2003 and 2005, the body mass of individual redstarts at the end of the dry season accurately predicted their migratory departure dates. Although total dry-season rainfall in 2003 was over 3 times that in 2005, rainfall in March of both years was $<20 \mathrm{~mm}$. In these years, low March rainfall likely contributed to the marked differences in food availability between mangrove and scrub habitats, helping to drive the between-habitat variation in body mass and its influence on spring departure schedules. In contrast, although total dry-season rainfall in 2003 and 2004 differed by $<50 \mathrm{~mm}$, over $100 \mathrm{~mm}$ of rainfall occurred in March 2004. Food availability in secondgrowth scrub and the body mass of birds in this habitat were higher following this rain pulse than at any other time during the study. Although redstart body mass in mangrove remained higher compared to birds in scrub, departure schedules in 2004 did not differ between habitats, and the relationship between body mass and the timing of departure was negligible. These results indicate that the timing of rainfall within the dry season, not just the absolute amount, may be critical for orchestrating migratory departure schedules of birds in drought-prone environments.

The quality of nonbreeding habitat can have important implications for the future reproductive success of migratory birds. Individuals wintering in high-quality habitats may arrive earlier at breeding sites and be in better physical condition compared to later arrivals (Marra et al. 1998, Gill et al. 2001). Delays in arrival of only a few days can reduce reproductive output by limiting the time available to replace failed clutches (Norris et al. 2004) or by preventing access to high-quality breeding habitat (Gunnarsson et al. 2006). The strong correlation we detected between the average body mass of redstarts at the end of the winter dry season and their average departure schedules in each year implies that the intensity of such carry-over effects could vary through time at individual nonbreeding sites or across spatial gradients in moisture at local and potentially regional scales. Because females predominate in dry, second-growth scrub (Marra \& Holmes 2001), carry-over effects following dry springs are likely to be more severe for this sex. Variation in nonbreeding season rainfall could also be of particular concern for species with small populations or restricted winter distributions, especially if drought-induced carry-over effects exacerbate other limiting factors on breeding areas.

Knowledge of the factors that shape the timing of departure from nonbreeding quarters may also be important for predicting how changing climate could alter the phenology of spring migration. When considered in the context of long-term trends in winter rainfall, our results suggest that conditions experienced by redstarts during their nonbreeding season could constrain adaptive responses to selection for earlier breeding that may result from rising temperatures on breeding areas. Over the past $11 \mathrm{yr}$, rainfall at our Jamaican study sites has declined by approximately $17 \%$. Moreover, consensus predictions from multiple models project drastic declines in rainfall throughout the Caribbean over the next 50 yr (Neelin et al. 2006). Because food availability appears dependent on rainfall, birds may face increasingly greater food limitation during the critical period of pre-migratory fueling, leading to progressively greater delays in the timing of departure on spring migration. Under this scenario, redstarts would be unable to respond to selection for earlier breeding by advancing their spring departure dates. Selection pressures imposed 
by extreme drought on nonbreeding areas could also compound the ability of some birds to complete their migration successfully. Preliminary data for redstarts indicate that the annual survival of large-bodied birds is low following severe winter dry seasons, and that small-bodied survivors migrate shorter distances to breeding areas, based on stable-hydrogen isotopes in feathers molted following reproduction (authors' unpubl. data). Because dry-season rainfall in Jamaica is also becoming increasingly variable, such pressures could lead to annually shifting adaptive peaks for body size rather than to sustained directional selection (Grant \& Grant 1989). How changing climate during the nonbreeding period might act on other targets of selection that could influence migration merits further study.

Further insights into the numerous potential responses migratory birds could display to changing climate during the nonbreeding season will require additional observational studies coupled with experiments. At present, the role of food as a limiting factor for nonbreeding season migratory birds in the Caribbean is known for only a handful of species. Food supplementation experiments with ovenbirds Seiurus aurocapilla (Brown \& Sherry 2006) and individual upgrade experiments with redstarts (Studds \& Marra 2005) clearly isolate the role of food and moisture as key limiting factors for birds during the latewinter dry season. Needed are long-term observational data and similar experimental approaches for Palearctic migrants while on their African and Asian nonbreeding grounds. Also needed are common garden and captive breeding experiments designed to clarify the relative role of genetic versus environmental controls on spring departure schedules. The latter will be particularly important for understanding how phenotypic plasticity and microevolutionary change could interact to shape spring migration schedules under changing environmental conditions (Pulido 2007, this issue).

Despite recent progress, our understanding of how climate during the nonbreeding season acts to affect individual condition, demography, and abundance of migratory passerines remains poor. Additional research during the nonbreeding period will help to develop a more synthetic view of how ongoing changes in climate in different phases of the annual cycle interact to influence year-round population processes in long-distance migratory birds. Such knowledge is critical to our understanding of population regulation (Sæther et al. 2004), to the development of models that predict population dynamics of migratory birds (Dolman \& Sutherland 1994, Runge \& Marra 2005), and to population management (Almaraz \& Amat 2004).
Acknowledgements. We are grateful to T. Biasiolli, D. Brown, K. Cramer, H. Davis, M. Evans, P. Goulet, J. Greenwood, Q. Hays, E. Klein, M. Reudink, and K. Strum for assistance in the field, to M. Thomas for help with arthropod analyses, and to R. Aviram, D. Inouye, and 2 anonymous reviewers for comments on the manuscript. This work was funded by the Cosmos Club Foundation, the Wilson Ornithological Society, the Smithsonian Predoctoral Fellowship Program (C.E.S.), and by National Science Foundation grants DEB-085965 and DEB-640195 (P.P.M.). We thank the Petroleum Corporation of Jamaica for permission to conduct this research at the Font Hill Nature Preserve, and Ms. Yvette Strong and Ms. Andrea Donaldson of the Jamaica National Environmental Planning Agency for their cooperation.

\section{LITERATURE CITED}

Almaraz P, Amat J (2004) Multi-annual spatial and numeric dynamics of the white-headed duck Oxyura leucocephala in southern Europe: seasonality, density dependence and climatic variability. J Anim Ecol 73:1013-1023

Barbraud C, Barbraud JC, Barbraud M (1999) Population dynamics of the white stork Ciconia ciconia in western France. Ibis 141:469-479

Both C, te Marvelde L (2007) Climate change and timing of avian breeding and migration throughout Europe. Clim Res 35: 93-105

Both C, Visser ME (2001) Adjustment to climate change is constrained by arrival date in a long-distance migratory bird. Nature 411:296-298

Both C, Artemyev AV, Blaauw B, Cowie RJ and others (2004) Large-scale geographical variation confirms that climate change causes birds to lay earlier. Proc R Soc Lond B Biol Sci 271:1657-1663

Both C, Sanz JJ, Artemyev AV, Blaauw B and others (2006) Pied flycathers Ficedula hypoleuca travelling from Africa to breed in Europe: differential effects of winter and migration conditions on breeding date. Ardea 94:511-525

Brown DR, Sherry TW (2006) Food supply controls physical condition of a long distance migrant bird wintering in the tropics. Oecologia 149:22-32

Cotton PA (2003) Avian migration phenology and global climate change. Proc Natl Acad Sci USA 100:12219-12222

Crick HQP, Dudley C, Glue DE, Thomson DL (1997) UK birds are laying eggs earlier. Nature 388:526

Dolman PM, Sutherland WJ (1994) The response of bird populations to habitat loss. Ibis 137:S38-S46

Dunn PO, Winkler WD (1999) Climate change has affected the breeding date of tree swallows throughout North America. Proc R Soc Lond B Biol Sci 266:2487-2490

Forchhammer MC, Post E, Stenseth NC (2002) North Atlantic Oscillation timing of a long- and short-distance migration. J Anim Ecol 71:1002-1004

Gill JA, Norris K, Potts PM, Gunnarsson TG, Atkinson PW, Sutherland WJ (2001) The buffer effect and large-scale population regulation in birds. Nature 412:436-438

Gordo O, Brotons L, Ferrer X, Comas P (2005) Do changes in climate patterns in wintering areas affect the timing of the spring arrival of trans-Saharan migrant birds? Glob Change Biol 11:12-21

Grant BR, Grant PR (1989) Natural selection in a population of Darwin's finches. Am Nat 133:377-393

Gunnarsson TG, Gill JA, Atkinson PW, Gélinaud G and others (2006) Population-scale drivers of individual arrival times in migratory birds. J Anim Ecol 75:1119-1127

Hitch AT, Leberg PL (2007) Breeding distributions of North American birds moving north as a result of climate change. Conserv Biol 21:534-539 
Huberty AF, Denno RF (2004) Plant water stress and its consequences for herbivorous insects: a new synthesis. Ecology 85:1383-1398

Hüppop O, Winkel W (2006) Climate change and timing of spring migration in the long-distance migrant Ficedula hypoleuca in central Europe: the role of spatially different temperature changes along migration routes. J Ornithol 147:344-353

Janzen DH (1973) Sweep samples of tropical foliage insects: effects of seasons, vegetation types, elevation, time of day, and insularity. Ecology 54:687-708

Johnson MD, Sherry TW, Holmes RT, Marra PP (2006) Assessing habitat quality for a migratory songbird wintering in natural and agricultural habitats. Conserv Biol 20:1433-1444

Kanyamibwa S, Schierer A, Pradel R, Lebreton JD (1990) Changes in adult annual survival rates in a western European population of the white stork Ciconia ciconia. Ibis 132:7-35

Lefebvre G, Poulin B, McNeil R (2004) Temporal dynamics of mangrove bird communities in Venezuela with special reference to migrant warblers. Auk 111:405-415

Marra PP, Holberton RL (1998) Corticosterone levels as indicators of habitat quality: effects of habitat segregation in a migratory bird during the non-breeding season. Oecologia 116:284-292

Marra PP, Holmes RT (2001) Consequences of dominance-mediated habitat segregation in a migrant passerine bird during the non-breeding season. Auk 118:92-104

Marra PP, Sherry TW, Holmes RT (1993) Territorial exclusion by a long-distance migrant warbler in Jamaica: a removal experiment with American redstarts (Setophaga ruticilla). Auk 110:565-572

Marra PP, Hobson KA, Holmes RT (1998) Linking winter and summer events in a migratory bird by using stable-carbon isotopes. Science 282:1884-1886

Marra PP, Francis C, Mulvihill R, Moore F (2005) The influence of climate on the timing and rate of spring bird migration. Oecologia 142:307-315

Mills AM (2005) Changes in the timing of spring and autumn migration in North American migrant passerines during a period of global warming. Ibis 147:259-269

Møller AP (1989) Population dynamics of a declining swallow Hirundo rustica population. J Anim Ecol 58:1051-1063

Murphy-Klassen HM, Underwood TJ, Sealy SG, Czyrnyj AA (2005) Long-term trends in spring arrival dates of migrant birds at Delta Marsh, Manitoba, in relation to climate change. Auk 122:1130-1148

Neelin JD, Münnich M, Su H, Meyerson JE, Holloway CE (2006) Tropical drying trends and global warming models and observations. Proc Natl Acad Sci USA 103:6110-6115

Nemani RR, Keeling CD, Hashimoto H, Jolly WM and others (2003) Climate-driven increases in global terrestrial net primary production from 1982 to 1999. Science 300:1560-1563

Norris DR, Marra PP, Kyser TK, Sherry TW, Ratcliffe LM (2004) Tropical winter habitat limits reproduction success in a migratory bird. Proc R Soc Lond B Biol Sci 271:59-64

Oba G, Post E, Stenseth NC (2001) Sub-Saharan desertification and productivity are linked to hemispheric climate variability. Glob Change Biol 7:241-246

Parmesan C, Yohe G (2003) A globally coherent fingerprint of climate change impacts across natural systems. Nature 421: $37-42$

Parrish JD, Sherry TW (1994) Sexual habitat segregation by American redstarts wintering in Jamaica: importance of resource seasonality. Auk 111:38-49

Peach WJ, Baillie SR, Underhill LG (1991) Survival of British sedge warblers Acrocephalus schoenobaenus in relation to West African rainfall. Ibis 133:300-305

Pettorelli N, Vik JO, Mysterud A, Gaillard JM, Tucker CJ, Stenseth NC (2005) Using the satellite-derived NDVI to assess ecological response to environmental change. Trends Ecol Evol 20:503-510

Polis GA, Hurd SD, Jackson CT, Pinero FS (1997) El Niño effects on the dynamics and control of an island ecosystem in the Gulf of California. Ecology 78:1884-1897

Pulido F (2007) Phenotypic changes in spring arrival: evolution, phenotypic plasticity, effects of weather and condition. Clim Res 35:5-23

Pyle P (1997) Identification guide to North American birds. Part I, Columbidae to Ploceidae. Slate Creek Press, Bolinas, CA, p 496-497

Root TL, Price JT, Hall KR, Schneider SH, Rosenzweig C, Pounds JA (2003) Fingerprints of global warming on wild animals and plants. Nature 421:57-60

Runge M, Marra PP (2005) A demographic model for a migratory passerine bird: population dynamics of the American redstart. In: Greenberg R, Marra PP (eds) Birds of two worlds: the ecology and evolution of migration. Johns Hopkins University Press, Baltimore, MD, p 375-389

Sæther BE, Sutherland WJ, Engen SJ (2004) Climate influences on avian population dynamics. Adv Ecol Res 35:185-209

Saino N, Szép T, Romano M, Rubolini D, Spina F, Møller AP (2004) Ecological conditions in winter predict arrival date at the breeding quarters in a trans-Saharan migratory bird. Ecol Lett 7:21-25

Saino N, Rubolini D, Jonzén N, Ergon T, Montemaggiori A, Stenseth NC, Spina F (2007) Temperature and rainfall anomalies in Africa predict timing of spring migration in transSaharan migratory birds. Clim Res 35:123-134

SAS Institute (1999) SAS/STAT Users guide, version 8.2. SAS Institute, Cary, NC

Sherry TW, Holmes RT (1997) American redstart (Setophaga ruticilla). In: Poole A, Gill F (eds) Birds of North America, No. 277. The Academy of Natural Sciences of Philadelphia, Philadelphia, PA and American Ornithologists' Union, Washington, DC

Sherry TW, Johnson MD, Strong AM (2005) Does winter food limit populations of migratory birds? In: Greenberg R, Marra PP (eds) Birds of two worlds: the ecology and evolution of migration. Johns Hopkins University Press, Baltimore, MD, p 414-425

Sillett TS, Holmes RT, Sherry TW (2000) Impacts of a global climate cycle on the population dynamics of a migratory songbird. Science 288:2040-2042

Studds CE, Marra PP (2005) Nonbreeding habitat occupancy and population processes: an upgrade experiment with a migratory bird. Ecology 86:2380-2385

Szép T (1995) Relationship between West African rainfall and the survival of central European Sans Martins Riparia riparia. Ibis 137:162-168

Szép T, Møller AP (2005) Using remote sensing data to identify migration and wintering areas and to analyze the effects of environmental conditions on migratory birds. In: Greenberg R, Marra PP (eds) Birds of two worlds: the ecology and evolution of migration. Johns Hopkins University Press, Baltimore, MD, p 390-400

Thomas CD, Lennon JJ (1999) Birds extend their ranges northwards. Nature 399:213

van den Brink B, Bijlsma RG, van der Have TM (2000) European swallows Hirundo rustica in Botswana during three nonbreeding seasons: the effects of rainfall on moult. Ostrich 71:198-204

Walther GR, Post E, Convey P, Menzel A and others (2002) Ecological responses to recent climate change. Nature 416: 389-395

Wolda H, Wright SJ (1992) Artificial dry season rain and its effects on tropical insect abundance and seasonality. Proc Koninklijke Nederlandse Akademie van Wetenschappen 95:535-548 